\title{
Preliminary Evaluation of the Antidiarrheal Effects of Ethanol Leaf Extract and Fractions of Rauwolfia vomitoria Afzel. (Apocynaceae)
}

\author{
A.E. Odenigbo ${ }^{1, a}$, P.A. Akah",b, E.E. llodigwe ${ }^{1, c}$, D.L. Ajaghaku³,d, \\ E.O. Erhirhie ${ }^{4, e}$, M. Ogbonnaya ${ }^{1, f}$, C.P. Ihekwereme ${ }^{1, g *}$
}

${ }^{1}$ Department of Pharmacology and Toxicology, Faculty of Pharmaceutical Sciences, Nnamdi Azikiwe University, Awka, Nigeria.

${ }^{2}$ Department of Pharmacology and Toxicology, Faculty of Pharmaceutical Sciences, University of Nigeria, Nsukka, Nigeria.

${ }^{3}$ Department of Pharmacology, Faculty of Pharmaceutical Sciences, Enugu State University of Science and Technology, Enugu State, Nigeria.

${ }^{4}$ Department of Pharmacology and Toxicology, Faculty of Pharmaceutical Sciences, Chukwuemeka Odumegwu Ojukwu University, Igbariam, Nigeria.

*Corresponding author: C.P. Ihekwereme Department of Pharmacology and Toxicology, Faculty of Pharmaceutical Sciences, Nnamdi Azikiwe University, Awka, PMB 420281 Nigeria.

Email: *cp.ihekwereme@unizik.edu.ng

Tel: +2347089817404, +2348034049012

Authors email addresses: aodenigboabeleke@yahoo.com, bpeterakah@hotmail.com, cee.ilodigwe@unizik.edu.ng, ddaniel.ajaghaku@esut.edu.ng, eerhirhieochuko@yahoo.com, fmbabte@yahoo.com, ${ }^{9}$ chibuezei@gmail.com

Keywords: Anti-spasmodic, Rauwolfia vomitoria, anti-diarrheal, ex-vivo model, albino mice.

Abstract. Context: Diarrhea, a major leading cause of death among under-five children in developing countries is still ravaging the society today due to limitations associated with conventional treatment approaches. The leaf of Rauwolfia vomitoria ( $R$. vomitoria) is used by the locals in Nigeria for the treatment of diarrhea. Aim: This study evaluated the anti-diarrheal activity of the leaf extract and fractions of $R$. vomitoria using animal models. Methods: Phytochemical screening of the extract was carried out. The extracts and fractions of $R$. vomitoria were screened using castor-oil induced diarrhea, castor-oil induced enteropooling, charcoal meal test and ex-vivo anti-spasmodic models. The tests groups received $400 \mathrm{mg} / \mathrm{kg}$ of the extract, $\mathrm{n}$-hexane, ethyl acetate and water fractions based on the result of preliminary study. Negative control group received $5 \mathrm{ml} / \mathrm{kg}$ of $5 \%$ Tween- 80 while Loperamide $(2 \mathrm{mg} / \mathrm{kg})$ and atropine sulphate $(10 \mathrm{mg} / \mathrm{kg})$ served as positive controls. Ex-vivo anti-spasmodic test was carried out using isolated guinea pig ileum. Results: Phytochemical test revealed the presence of alkaloids, saponins, tannins, flavonoids, cardiac glycoside, terpenoids and steroids. In castor oil-induced diarrhea model, $400 \mathrm{mg} / \mathrm{kg}$ of the extract and fractions significantly $(\mathrm{p} \leq 0.05)$ prolonged diarrhea onset, decreased frequency of defecation, weight of feces, and volume of intestinal content. The extract and n-hexane fraction produced more antidiarrheal activity in castor oil -induced enteropooling and charcoal meal test models. The extract exhibited a dose dependent inhibition of acetylcholine induced contraction of isolated ileum. Conclusion: Results obtained from the study validate the folkloric use of $R$. vomitoria leaf extract in the treatment of diarrhea.

\section{Introduction}

In Nigeria and other developing countries, diarrhea remains the second-leading cause of death in children younger than five years of age $[1,2]$. It is characterized by increased gastrointestinal motility, secretion and decrease in the absorption of fluids and electrolytes [3]. These symptoms remain a concern to patients' treatment.

Recent estimate revealed that about 3 to 5 billion cases of diarrhea occur every year which results in 1 million deaths among children under the age five [4]. 
Oral rehydration therapy (ORT) being the key strategy for effective management and has been instrumental in reducing diarrhea related mortalities. However, patients are often dissatisfied with ORT since it does not decrease the frequency of stools. The anti-motility agents are sufficient for infectious diarrhea. Furthermore, there is increase in resistance of infectious diarrhea organisms to antibiotics [5, 6].

Medicinal plants on the other hand, have been the foundation of traditional medicine throughout the world and continue to nurture mankind with new remedies. Herbal medicines are gaining more grounds for the prevention and treatment of diarrhea due to their accessibility, affordability and safety $[7,6]$. Thus, natural botanicals remain an important niche for development of more effective antidiarrheal agents.

Rauwolfia vomitoria, belonging to the family of Apocynaceae, commonly called Swizzle stick, is widely distributed in different parts of Nigeria and other parts of the world. It is widely used for the management and treatment of several disorders such as dysentery, jaundice, snakebites, gastrointestinal disturbances, hypertension among others [8].

Phytochemical studies revealed that it possesses various bioactive molecules including alkaloids, saponins, tannins, steroids, flavonoids and cardiac glycosides, which justify its numerous medicinal uses $[9,10]$. Reported pharmacological activities on $R$. vomitoria include anti-cancer [11], lipid lowering [12], teratogenic [13], anthelmintic [14], anti-filarial [15] activities, among others. Ezeigbo et al., [16] have reported that the methanol leaf extract of a Rauwolfia serpentine (R. serpentina), a related specie of $R$. vomitoria showed antidiarrheal activity in castor oil induced diarrheal model. An ethnobotanical survey reviewed that the leaf extract of $R$. vomitoria is used by traditional healers of Abakaliki, Ebonyi State (South-Eastern Nigeria) for the treatment of various stomach disorders including diarrhea. This present study was undertaken to validate the potential of ethanol leaf extract and fractions $R$. vomitoria using in-vivo and ex-vivo experimental models of diarrheal.

\section{Materials and Methods}

\section{Materials}

\section{Apparatus}

Refrigerator (Thermacol),Electronic weighing balance (Scout Pro Spu 401: S/N : 7126140063), water bath, separating funnel, syringes, test tubes, beakers, measuring cylinder, filter paper, hand gloves.

\section{Chemicals}

Ethanol (70\%), methanol (100\%), n-hexane, ethyl acetate - (BDH Chemical Ltd England), acetylcholine, Tween 80 .

\section{Experimental animals}

Albino mice and rats of either sex were procured from the animal facility of the Faculty of Pharmaceutical Sciences, Nnamdi Azikiwe University, Awka, Nigeria. Animals were given access to feed and water ad libitum. Experiments were performed in compliance with the institutional and international policies governing the human and ethical treatment of experimental animals as contained in the United States National Institutes for Health Guidelines (1985).

\section{Methods}

\section{Plant collection and authentication}

R. vomitoria was collected from a farm in Amike Aba, Ebonyi Local Government Area, Ebonyi State, Nigeria. Botanical identification and authentication was done by Mr. P. O. Ugwuozor of the Department of Botany, Nnamdi Azikiwe University, Awka, Anambra State, Nigeria. 


\section{Preparation of extract and fractions}

Fresh leaves of $R$. vomitoria were air dried for three weeks and pulverized using a grinding machine and stored in an air-tight container. Thereafter, $1.5 \mathrm{~kg}$ of the blended leaves was cooled macerated in $6 \mathrm{~L}$ of ethanol for 72 hours at room temperature $\left(25^{\circ} \mathrm{C}\right)$. The filtrate recovered was evaporated to dryness overwater bath at a temperature of $65^{\circ} \mathrm{C}$. A portion of the extract $(24 \mathrm{~g})$ was dispersed in distilled water and successively fractionated in separating funnel using n-hexane and ethyl acetate to yield n-hexane, ethyl acetate and aqueous fractions. Each fraction was concentrated to dryness over water bath at a temperature of $65^{\circ} \mathrm{C}$ and stored at $4{ }^{\circ} \mathrm{C}$ prior to use.

Phytochemical analysis: The extracts were screened for the presence of alkaloids, flavonoids, tannins, saponins, steroid, alkaloids and glycosides using standard methods $[17,18]$.

\section{Acute toxicity test}

The acute toxicity ( $\left.\mathrm{LD}_{50}\right)$ study was carried out following modified Lorke's method described by Erhirhie et al [19]. Animals (rats and mice) of either sex were fasted overnight prior to the study. The test was carried out in two phases.

In phase one, nine mice were randomized into three groups of three mice each and were given 10, 100 or $1000 \mathrm{mg} / \mathrm{kg}$ body weight of the extract by oral route. Animals in each group were observed for signs of toxicity and mortality in the first four hours and subsequently at 24 hours. In phase two, another fresh set of three mice were randomized into three groups of one mouse each, and were given 1600,2900 and $5000 \mathrm{mg} / \mathrm{kg}$ body weight of the extract. This phase was carried out based on the result obtained from phase one. The animals were also observed for signs of toxicity and mortality in the first four hours and subsequently for 24 hours. The $\mathrm{LD}_{50}$ was calculated as the geometric mean of the highest non-lethal dose and the least toxic dose.

\section{Experimental Design}

\section{Determination of antidiarrheal activity}

\section{Pilot study}

A pilot study to determine the effective dose of the extract was carried out using 25 mice randomized into five (5) groups of five animals each. The mice were fasted for 18 hours. Diarrhea was induced using castor oil. Group 1 served as control and received $5 \mathrm{ml} / \mathrm{kg} \mathrm{5 \%}$ Tween- 80 while groups $2-5$ received $100,200,400$ or $800 \mathrm{mg} / \mathrm{kg}$ of ethanol leaf extract of $R$. vomitoria orally. Thirty minutes after castor oil administration $(0.2 \mathrm{ml} / \mathrm{mouse})$, each group of the animal was treated with various doses of the extract and placed in their individual cages. Thereafter, onset of diarrhea, number of wet feces and total weight of fecal output were observed and recorded within 6 hours. Percentage inhibition (P.I) for each parameter was calculated using the formula:

P.I $=(\mathbf{1 0 0}-(\mathrm{X} / \mathrm{Y} \times \mathbf{1 0 0})$

Where $\mathbf{X}=$ total number of wet feces in treated group, $\mathbf{Y}=$ total number of wet feces in control group.

\section{Main study}

\section{Castor oil-induced diarrhea}

Having established the effective dose of $400 \mathrm{mg} / \mathrm{kg}$ in the pilot study, another set of 30 mice were fasted for 18 hours and randomized into 6 groups of 5 mice each as follow; group 1(control, received $5 \mathrm{ml} / \mathrm{kg} \mathrm{5 \%}$ Tween- 80), group 2 (standard, received Loperamide, $2 \mathrm{mg} / \mathrm{kg}$ ), group 3-6 (received $400 \mathrm{mg} / \mathrm{kg}$ of the leaf extract, n-hexane, ethyl acetate and water fractions respectively) [6] Animals were treated following the same pattern described in the pilot study above.

\section{Gastrointestinal Motility Test}

A total of 30 mice were fasted for 18 hours and randomized into 6 groups of 5 mice each as follow; group 1 (received $5 \mathrm{ml} / \mathrm{kg} \mathrm{5 \%}$ Tween 80), group 2 (received atropine sulphate $10 \mathrm{mg} / \mathrm{kg}$ ), groups 3, 4,5 , and 6 (received $400 \mathrm{mg} / \mathrm{kg}$ of ethanol extract, n-hexane, ethyl acetate, and aqueous fractions 
respectively). All treatments were given by oral route. Thirty minutes later, each animal was given charcoal meal $(0.2 \mathrm{ml} /$ mouse $)$ orally. Mice were sacrificed after 30 minutes and the small intestine was isolated immediately and placed on a transparent paper. Distance travelled by charcoal meal was measured with the aid of a meter rule. The peristaltic index, distance traveled by the charcoal meal relative to the total length of small intestine expressed in percentage was determined for each mouse [20].

Percentage inhibition (P.I) of intestinal transit was calculated using the formula:

$\mathbf{P . I}=\mathbf{( 1 0 0}-(\mathrm{X} / \mathrm{Y} \times \mathbf{1 0 0})$

Where $\mathbf{X}=$ percentage distance in treated group,

$\mathbf{Y}=$ percentage distance in control group.

\section{Castor oil-induced enteropooling test}

The intraluminal fluid accumulation was determined by the method described by Sadraei et al [21] and Emudainohwo et al [22]. A total of 30 mice were fasted for 18 hours and randomized into 6 groups of 5 mice each as follow; group 1 (received $5 \mathrm{ml} / \mathrm{kg} 5 \%$ Tween 80), group 2 (received Loperamide, $5 \mathrm{mg} / \mathrm{kg}$ ), groups 3-6 (received $400 \mathrm{mg} / \mathrm{kg}$ of extract, n-hexane, ethyl acetate, and aqueous fractions respectively). One hour after treatment, the mice received castor oil $(0.2$ $\mathrm{ml} /$ mouse) orally. Mice were sacrificed 1 hour later and the small intestines were removed after ligation at the pyloric end and ileocaecal junction and weighed. The contents of intestines were expelled into graduated tubes and their volumes were measured. The intestine was reweighed and the difference between the full and empty intestine was determined.

Percentage reduction (P.I) of intestinal content was calculated using the formula:

$\mathbf{P . I}=(\mathbf{1 0 0}-(\mathrm{X} / \mathrm{Y} \times \mathbf{1 0 0})$

Where $\mathbf{X}=$ volume of the intestinal content in treated group,

$\mathbf{Y}=$ volume of the intestinal content in control group.

\section{Evaluation of anti-microbial activity of the plant extract}

\section{Microorganisms}

Salmonella spp, Staphylococcus aureus (Staph. aureus), Bacillus subtilis (B. subtilis) and Escherichia coli (E. coli) were obtained from the laboratory stock of the Department of Pharmaceutical Microbiology and Biotechnology, Nnamdi Azikiwe University, Agulu campus. The organisms were sub-cultured prior to the experiment.

\section{Antimicrobial assay}

Antimicrobial activities of the plant extracts were determined by the agar-well diffusion method as described by Esimone et al. [23].

Selective media, Mannitol salt, Salmonella Shigellae, Nutrient and Mackonkey agars were also used for specific detection bacteria, Staphylococcus aureus, Salmonella typhi, Bacillus subtilis and Escherichia coli respectively.

Cultures of bacteria were adjusted to $0.5 \mathrm{McFarland}$ turbidity standards and the test organisms were seeded onto sterile Mueller-Hinton Agar MHA (Oxoid, Difco USA) using sterile swab, (diameter: $90 \mathrm{~mm}$ ). A well of $6 \mathrm{~mm}$ diameter was made using sterile cork borer on each of the MHA. Different concentrations $(6.5,12.525 \mathrm{mg} / \mathrm{ml})$ of the ethanol extract and n-hexane fraction from stocks of 100 $\mathrm{mg} / \mathrm{ml}$ were used for the bioassay. Gentamycin $(5 \mu \mathrm{g})$ was used as a standard antibacterial agent. (200 $\mathrm{mg}$ of each extract was dissolved in $2 \mathrm{ml}$ of sterile distilled water. Aliquot $(80 \mu \mathrm{l})$ of each concentration was applied in each of the wells in the culture plates previously seeded with the test organism. The cultures were incubated at $37^{\circ} \mathrm{C}$ for $24 \mathrm{hrs}$. Antimicrobial activity was determined by measuring the zone of inhibition (ZOI) around each well (excluding the diameter of the well) and results were expressed in millimeters $(\mathrm{mm})$. Each concentration was tested in duplicate against the test organisms. 


\section{Determination of spasmolytic activity}

A guinea pig was fasted for 12 hours and exsanguinated after cervical dislocation. The ileum was isolated and trimmed of adherent tissues. A $2 \mathrm{~cm}$ tissue segment was suspended in $15 \mathrm{ml}$ organ bath containing Tyrode's solution bubbled with carbogen and maintained at $37^{\circ} \mathrm{C}$. Composition of Tyrode's solution per liter include sodium chloride, $(8.0 \mathrm{~g})$, potassium chloride $(0.2 \mathrm{~g})$, calcium chloride $(0.2 \mathrm{~g})$, sodium carbonate $(1.0 \mathrm{~g})$, magnesium chloride $(0.1 \mathrm{~g})$, sodium hydro- gen phosphate $(1.0 \mathrm{~g})$, and glucose $(2.0 \mathrm{~g})$. The rhythmic and spontaneous responses of ileum were recorded via isotonic force transducers (MLT0202) coupled through Bridge Amplifier (Model F221) to power Lab data acquisition system (AD instrument, Syndey, Australia). A preload of 1.0g was exercised and the tissues were allowed to equilibrate for $1 \mathrm{hr}$ prior to the addition of various concentrations, 2, 4, 8, 16, 32 and $64 \mathrm{mg} / \mathrm{ml}$ of extract [24].

\section{Data analysis}

Data were analyzed using by one way analysis of variance (ANOVA) followed by post hoc turkey's test using Instat ${ }^{\circledR}$ (Graph Pad Prism software, U.S.A). Results were presented as mean \pm standard error of mean $(\mathrm{SEM}), \mathrm{n}=5$. Statistical significant was considered when $\mathrm{p} \leq 0.05$. Graphical illustrations were carried out using Microsoft excel version 2010.

\section{Results}

\section{Acute oral toxicity test}

From the acute toxicity test, there was no mortality or signs of toxicity in both phases and doses, including $5000 \mathrm{mg} / \mathrm{kg}$.

\section{Phytochemical screening}

The phytochemical analysis of the ethanol extract showed the presence of bioactive compounds, alkaloids, tannins, cardiac glycosides, terpenoids, flavonoids, steroids and saponins. Resins were absent (Table 1).

Table 1: Photochemical constituents of $R$. vomitoria extract.

\begin{tabular}{lc}
\hline Constituents & Abundance \\
Alkaloids & + \\
Saponins & + \\
Tannins & + \\
Flavonoids & + \\
Cardiac glycoside & + \\
Resins & - \\
Terpenoids & + \\
Steroids & + \\
\hline
\end{tabular}

Note: Absent (-), Present (+).

\section{Antidiarrheal studies}

The result of the pilot study showed that $400 \mathrm{mg} / \mathrm{kg}$ of extract produced the highest significant $(p<0.05)$ inhibition on total number and weight of diarrhea feces when compared with control and other test doses. It also had the highest onset (Table 2). 
Table 2: Effect of ethanol extract on castor oil-induced diarrhea.

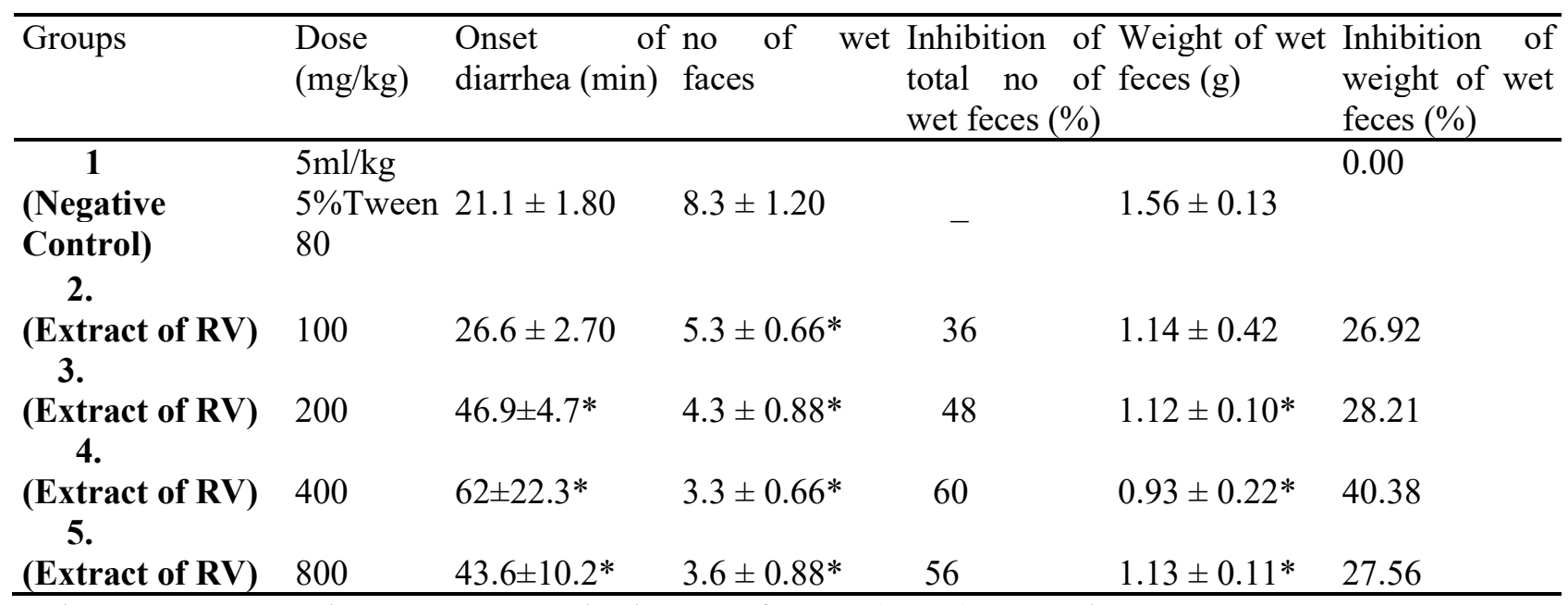

Values are presented as mean \pm standard error of mean $(\mathrm{SEM}), \mathrm{n}=5 .{ }^{*} \mathrm{p}<0.05 . \mathrm{RV}: R$. vomitoria.

\section{Effect of ethanol extract and fractions of R.vomitoria on castor oil-induced diarrhea}

The ethanol extracts and fractions of $R$. vomitoria at dose of $400 \mathrm{mg} / \mathrm{kg}$ produced significant $(\mathrm{P}<$ $0.05)$ inhibition against castor oil-induced diarrhea. The ethanol extract produced the highest inhibition (45\%), followed by n-hexane (40\%), ethyl acetate $(35 \%)$ and aqueous $(25 \%)$ fraction. The total weight of wet faeces decreased in similar manner; ethanol extract $(40.38 \%)>n$-hexane $(28 \%)>$ ethyl acetate $(28 \%)$ and aqueous $(27 \%)$ fractions (Table 3$)$. Activities posed by the extract and fractions were not comparable to the standard, Loperamide (65 and 86\%).

Table 3: Effect of extract and fractions of $\boldsymbol{R}$. vomitoria on castor-oil induced diarrhea.

\begin{tabular}{|c|c|c|c|c|c|c|}
\hline Groups & $\begin{array}{l}\text { Dose } \\
(\mathrm{mg} / \mathrm{kg})\end{array}$ & $\begin{array}{ll}\text { Onset } & \text { of } \\
\text { diarrhea } \\
(\min )\end{array}$ & $\begin{array}{l}\text { No of wet } \\
\text { feces }\end{array}$ & $\begin{array}{l}\text { Inhibitionof } \\
\text { total no of } \\
\text { wet faeces } \\
(\%)\end{array}$ & $\begin{array}{l}\text { Total weight of } \\
\text { wet faeces }\end{array}$ & $\begin{array}{l}\text { Inhibition of } \\
\text { total weight of } \\
\text { wet faeces }(\%)\end{array}$ \\
\hline \begin{tabular}{l}
\multicolumn{1}{c}{1.} \\
Negative \\
Control
\end{tabular} & $\begin{array}{l}5 \mathrm{ml} / \mathrm{kg} \\
5 \% \\
\text { Tween } 80\end{array}$ & $28.6 \pm 1.80$ & $4 \pm 0.31$ & - & $1.56 \pm 0.13$ & - \\
\hline $\begin{array}{l}2 . \\
\text { Extract of RV }\end{array}$ & 400 & $56 \pm 14.13^{*}$ & $2.2 \pm 0.66^{*}$ & 45 & $0.93 \pm 0.22 *$ & 40 \\
\hline $\begin{array}{l}\quad 3 . \\
\text { n-hexane } \\
\text { fraction of RV }\end{array}$ & 400 & $46.8 \pm 4.68^{*}$ & $2.4 \pm 0.40^{*}$ & 40 & $1.12 \pm 0.10^{*}$ & 28 \\
\hline $\begin{array}{l}\quad 4 . \\
\text { Ethyl-acetate } \\
\text { fraction of RV }\end{array}$ & 400 & $42.6 \pm 11.2 *$ & $2.6 \pm 0.67^{*}$ & 35 & $1.13 \pm 0.11^{*}$ & 28 \\
\hline $\begin{array}{l}\quad 5 . \\
\text { Aqueous } \\
\text { fraction of RV }\end{array}$ & 400 & $25 \pm 10.25$ & $3 \pm 1.52$ & 25 & $1.14 \pm 0.42 *$ & 27 \\
\hline $\begin{array}{c}6 . \\
\text { Loperamide }\end{array}$ & 2 & $61.6 \pm 21.36^{*}$ & $1.4 \pm 0.50^{*}$ & 65 & $0.22 \pm 0.91^{*}$ & 86 \\
\hline
\end{tabular}

Values are presented as mean \pm standard error of mean (SEM), $\mathrm{n}=5 . \mathrm{P}<0.05 . \mathrm{RV}: R$. vomitoria.

\section{Effects on gastrointestinal transit}

From table 4, n-hexane fraction and ethanol extract (except ethyl acetate fraction) significantly $(p<0.05)$ reduced the intestinal transit, but with lesser activities when compared to that of atropine. 
Table 4: Effect of extract and fractions $R$. vomitoria on gastro-intestinal motility.

\begin{tabular}{|c|c|c|c|c|c|}
\hline Groups & $\begin{array}{l}\text { Dose } \\
\mathrm{mg} / \mathrm{kg}\end{array}$ & $\begin{array}{l}\text { Distance } \\
\text { traveled by } \\
\text { charcoal meal } \\
\text { (meter) }\end{array}$ & $\begin{array}{l}\text { Total length of } \\
\text { the intestine } \\
\text { (meter) }\end{array}$ & $\begin{array}{l}\text { Percentage } \\
\text { distance }(\%)\end{array}$ & $\begin{array}{l}\text { Inhibition } \\
(\%)\end{array}$ \\
\hline \begin{tabular}{l}
\multicolumn{1}{c}{1.} \\
Negative \\
Control
\end{tabular} & $\begin{array}{l}5 \mathrm{ml} / \mathrm{kg} \\
5 \% \text { Tween } \\
80\end{array}$ & $36.3 \pm 4.54$ & $41.5 \pm 3.42$ & $86.57 \pm 6.47$ & 0 \\
\hline $\begin{array}{ll}2 . & \\
\text { Crude } & \text { extract } \\
\text { of } R V & \end{array}$ & 400 & $23.1 \pm 2.87$ & $40.5 \pm 2.76$ & $58.44 \pm 9.59 *$ & 32.5 \\
\hline $\begin{array}{l}\text { 3. } \\
\text { n-hexane } \\
\text { fraction of RV }\end{array}$ & 400 & $23.7 \pm 3.19^{*}$ & $48.6 \pm 2.24$ & $48.39 \pm 5.12 *$ & 44.1 \\
\hline $\begin{array}{l}4 . \\
\text { Ethyl acetate } \\
\text { fraction of } R V\end{array}$ & 400 & $36.6 \pm 7.06$ & $42.6 \pm 2.47$ & $85.42 \pm 14.57$ & 1.3 \\
\hline $\begin{array}{l}5 . \\
\text { Aqueous } \\
\text { fraction of RV }\end{array}$ & 400 & $33 \pm 4.36^{*}$ & $40.8 \pm 3.47$ & $81.23 \pm 8.12 *$ & 6.17 \\
\hline $\begin{array}{c}6 . \\
\text { Atropine } \\
\text { sulphate }\end{array}$ & 10 & $15.2 \pm 2.72^{*}$ & $37 . \pm 2.80$ & $41.92 \pm 9.90 *$ & 51.6 \\
\hline
\end{tabular}

Values are presented as mean \pm standard error of mean (SEM), $\mathrm{n}=5 . \mathrm{P}<0.05 . \mathrm{RV}: R$. vomitoria.

\section{Effects on castor oil-induced enteropooling}

Inhibition against castor oil-induced enteropooling by the extract and fractions follow a similar trend. The ethanol extract $(68.9 \%)$, n-hexane fraction (65.2\%), except ethyl acetate fraction, 3.03\%) significantly $(\mathrm{p}<0.05)$ reduced intestinal transit, but with lesser activities when compared to that of Loperamide (71.9\%) (Table 5).

Table 5: Effect of extract and fractions of $\boldsymbol{R}$. vomitoria on castor oil-induced enteropooling.

\begin{tabular}{llllll}
\hline Groups & Dose $(\mathrm{mg} / \mathrm{kg})$ & $\begin{array}{l}\text { Weight } \\
\text { intestinal } \\
\text { content }(\mathrm{g})\end{array}$ & $\begin{array}{l}\text { of } \\
\text { Volume } \\
\text { intestinal content } \\
(\mathrm{g})\end{array}$ & $\begin{array}{l}\text { Inhibition of the volume } \\
\text { of the intestinal content } \\
(\%)\end{array}$ \\
\hline Control & $\begin{array}{l}5 \mathrm{ml} / \mathrm{kg} \\
\text { Tween } 80\end{array}$ & $5 \%$ & $2.11 \pm 0.22$ & $1.32 \pm 0.07$ & - \\
$\begin{array}{l}\text { Crude extract } \\
\text { of RV } \\
\text { n-hexane } \\
\text { fraction of RV }\end{array}$ & 400 & $1.28 \pm 0.16^{*}$ & $0.41 \pm 0.06^{*}$ & 68.9 \\
$\begin{array}{l}\text { Ethyacetate } \\
\text { fraction of RV }\end{array}$ & 400 & $1.51 \pm 0.14^{*}$ & $0.46 \pm 0.11^{*}$ & 65.2 \\
$\begin{array}{l}\text { Aqueous } \\
\text { fraction of RV } \\
\text { Loperamide }\end{array}$ & 400 & $1.92 \pm 0.20$ & $1.28 \pm 0.43 *$ & 3.03 \\
\hline
\end{tabular}

Values are presented as mean \pm standard error of mean $(\mathrm{SEM}), \mathrm{n}=5 . \mathrm{P}<0.05$. $\mathrm{RV}:$ R. vomitoria. 


\section{Antimicrobial activities of the $R$. vomitoria Extract.}

The extract and n-hexane fraction did not inhibit the growth of selected organism, Staph. aureus, E. coli, Salmonella and B. subtilis ethanol extracts when compared with the standard, Gentamycin, 5 $\mu \mathrm{g}$ (Table 6).

Table 6: Antimicrobial activity of ethanol extracts and n-hexane fraction.

\begin{tabular}{lccccc}
\hline & Conc (mg/ml ) & Staph. aureus & E. coli & $\begin{array}{c}\text { Salmonella } \\
\text { typhi }\end{array}$ & B. subtilis \\
\hline Ethanol & 50 & & Inhibition zone diameter (mm) & \\
Extract & 100 & - & - & - & - \\
& 200 & - & - & - & - \\
N-hexane & 50 & - & - & - & - \\
fraction & 100 & - & - & - & - \\
& 200 & - & - & - & - \\
Gentamycin & $5 \mu \mathrm{g}$ & $\overline{25}$ & $\overline{40}$ & $\overline{32}$ & $\overline{10}$ \\
\hline
\end{tabular}

Antispasmodic activity of $\boldsymbol{R}$. vomitoria extracts on castor -oil induced diarrhea.

The extract significantly $(\mathrm{p}<0.05)$ inhibited acetylcholine induced contraction of isolated ileum in dose dependent manner (figure 1).

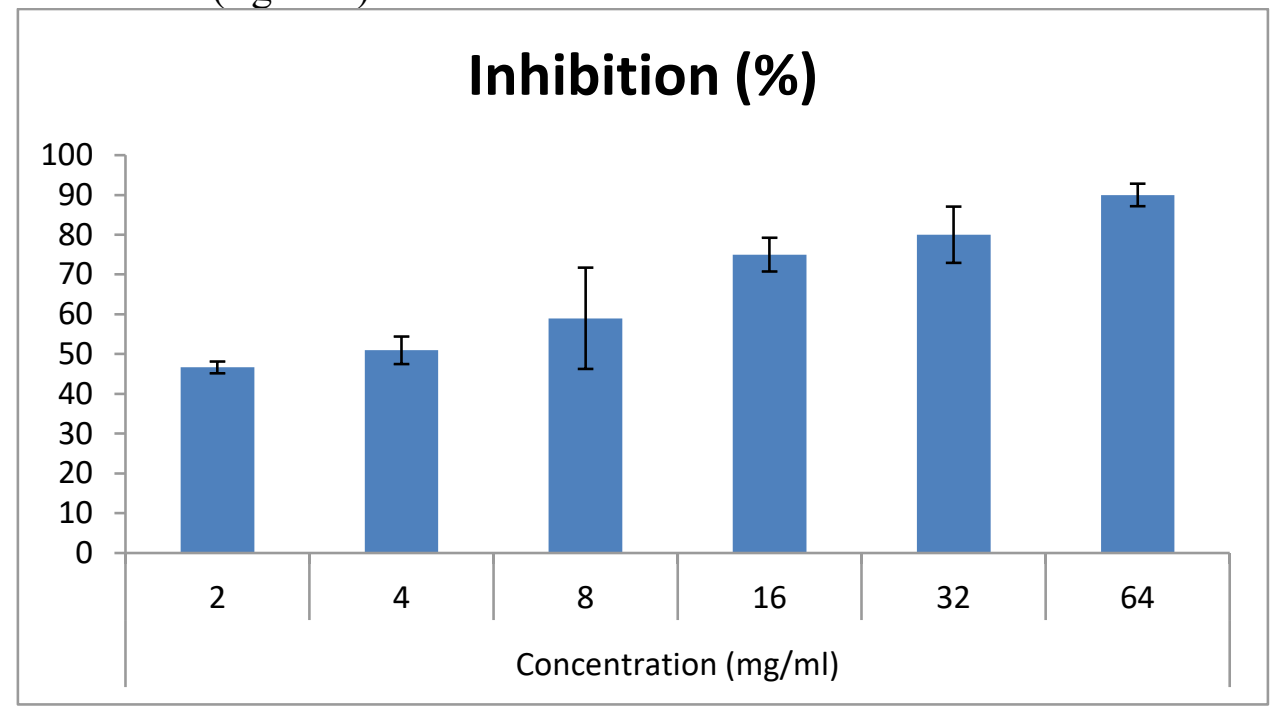

Values are presented as mean \pm Standard deviation, $\mathrm{n}=2$ (Isolated tissue experiment).

Figure 1: Showing inhibition of acetylcholine induced contraction on isolated ileum.

\section{Discussion}

The present study evaluated the antidiarrheal activity of the ethanol leaf extract and fractions of $R$ vomitoria using castor-oil induced diarrhea, castor-oil induced enteropooling, charcoal meal test and ex-vivo anti-spasmolytic models.

There was no death reported in the acute toxicity test, suggesting that the extract is relatively safe following single use.

From the in-vivo antidiarrheal models, the extract and fractions produced significant reduction on total number and weight of wet stools as well as delay in onset of castor oil-induced diarrhea. This suggests that the extract and fractions prevent the anti-secretory mechanism of castor oil induces diarrhea due to their active component.

This is supported by Ezeigbo et al., [16] who reported that the methanol leaf extract of a R. serpentine, a related specie of $R$. vomitoria exhibited antidiarrheal activity against castor oil-induced 
diarrheal model. Castor oil induced diarrhea is related to the stimulation of prostaglandins biosynthesis [21]. Release of ricinoleic acid by the action of lipases in the upper part of the small intestine binds to $\mathrm{EP}_{3}$ Prostanoid receptors on smooth muscle cells thereby facilitating the accumulation and secretion of fluids and electrolytes $[25,26]$.

Castor oil is known to cause an accumulation of water and electrolytes in intestinal loop. In the castor oil induced enteropooling test, the extract and n-hexane fraction significantly reduced the intraluminal fluid accumulation when compared to the control. The maximal effect of the extract was similar to Loperamide. This suggests that the leaf extracts produced relief in diarrhea by spasmolytic activity in vivo and enteropooling effects [27].

Mostly, anti-diarrheal agents act by decreasing secretion or reducing the propulsive movement of GI smooth muscles [28]. This prompted the selection of charcoal meal test as an additional model. Atropines sulfate $10 \mathrm{mg} / \mathrm{kg}$, extract and $\mathrm{n}$-hexane fraction at $400 \mathrm{mg} / \mathrm{kg}$ produced significant reduction in GI motility evidenced by reduction in distance travelled by charcoal meal. Islam et al., [29] suggested that antidiarrheal agents decrease motility of the gut muscles and increases the retention of substances in the intestine. This allow a greater time for reabsorption to occur. Thus, reduction in the intestinal propulsive movement in the charcoal meal model may be due to the antimotility property of the extract and fractions, thereby increasing the reabsorption of water and electrolytes. Atropine is a competitive antagonist of the muscarinic acetylcholine and anticholinergic. Its biological activity has to regulate the excitation of cholinergic fiber in abdominal organs. Administrations of Atropine sulfate causes a relaxation of the smooth muscles, inhibition of contracting motility and thereby inhibit small intestine movement [28].

In castor oil induced enteropooling, the reference drug produced more significant reduction in fluid accumulation followed by the extract and n-hexane fraction. This suggests that the ethanol leaf extract of $R$. vomitoria could also inhibit induced intestinal fluid accumulation. The antienteropooling activity of the extract could also be related to the existence of flavonoids, steroids and tannins. Tannins have been reported to precipitate the proteins in the intestinal mucosa by forming the protein tannates, which make the intestinal mucosa more resistance to chemical alteration and hence reduce the peristaltic movement and intestinal secretion [30]. Flavonoids and steroids have also been shown to modify the production of cyclooxygenase 1 and 2 (COX-1, COX-2) and lipooxygenase thereby inhibiting prostaglandin production, inhibiting secretion induced by castor oil and facilitating absorption of electrolytes [31,32]. On this not, it could be hypothesized that the antidiarrheal action exerted by the extract and fractions may be associated with the inhibition of prostaglandin formation.

The leaf extracts of $R$. vomitoria could not produce antimicrobial activity. It may be that the leaf extract does not possess antimicrobial activity or the organisms used showed resistance. This is in disagreement with the studies of Pasewu et al., [33] and Sonibare et al., [34] who reported that the root of $R$. vomitoria recorded antibacterial activity against E. coli, $S$. aureus and $P$. aeruginosa which was attributed to the presence of phytochemicals especially the flavonoids. These contradictions may be due to the extraction method and parts of $R$. vomitoria used by authors.

The in-vitro study of the ethanol leaf extract produced antispasmodic activity by antagonizing the actions of acetylcholine. This substantiates its anti-spasmodic effect in the gastrointestinal muscles. Smooth muscle contraction depends not only on extracellular $\mathrm{Ca}^{2+}$, but also intracellular $\mathrm{Ca}^{2+}$. In $\mathrm{Ca}^{2+}$-free solution, the acetylcholine-induced contraction is caused by the release of intracellular $\mathrm{Ca}^{2+}[28]$. Thus, the inhibitory actions of the leaf extract of $R$. vomitoria may be due to interference with $\mathrm{Ca}^{2+}$ movement.

\section{Conclusion}

This study showed that the ethanol leaf extract and fractions $R$. vomitoria produced significant antidiarrheal activity which may be attributed to its phytoconstituents. The antidiarrheal action of the extracts may be mediated through anti-secretory and antispasmodic mechanisms. This study provides a scientific basis for to the traditional use of $R$. vomitoria for the treatment of diarrhea. 


\section{Conflict of Interest}

Nil

\section{Acknowledgements}

Nil

\section{References}

[1] T. Edlam, et al., Evaluation of the anti-diarrheal activity of the aqueous stem extract of Lantana camara Linn (Verbenaceae) in mice, BMC Complementary and Alternative Medicine. 17(2017) 190.

[2] M. Belay. et al., Anti-diarrhoeal Activity of $80 \%$ Methanolic Leaf Extracts of Justicia schimperiana, Evidenced-Based complementary and Alternative Medicine. Volume 2018. Pp10.

[3] A. Abuhamdah et al., Spasmolytic and anti-microbial Activities of Crude extracts of Bongardia chrysogonum L. Tubers, International Journal of Pharmacology. 52 (2017) 60.

[4] V. Raj, A. Rai, M. Singh, Detection of bioflavonoids from methanol bark extracts of Acacia and their role as antidiarrhoeal agents, J Anal Pharm Res. 5(2017) 1-7.

[5] M.J. Farthing. Antisecretory drugs for diarrhoeal disease, Digestive diseases. 24 (2016) 47-58.

[6] C.P. Ihekwereme et al., Antidiarrheal property of Napoleona imperialis may be due to Procyanidins and Ellagic acid derivatives, Journal of Applied Pharmaceutical Science. 6 (2016) 101-106.

[7] A. Degu, E. Engidawork, W. Shileshi W, Evaluation of the anti-diarrhoeal activity of the leaf extract of Croton macrostachyus Hocsht ex Del.(Euphorbiaceae) in mice, BMC Complementary and Alternative medicine. 16 (2014) 379.

[8] M.U. Eteng, H.A. Ibekwe, A.O. Abolaji, A.I. Okoi, Onwuka, F.C. N.C. Osuchukwu. Effect of Rauwolfia vomitoria Afzel (Apocynaceae) extract on serum amino transferase and alkaline phosphatase activities and selected indices of liver and kidney functions, African Journal of Biotechnology 8 (2013) 4604-4607.

[9] L. Douglas. Rauwolfia in the Treatment of Hypertension, Integrative Medicine 14 3(2015) 4046.

[10] O.O. Amole, A.O. Onabanjo. Reserpine: The effect and uses of Rauwolfia vomitoria. Journal of Chemotherapy, 3 (1999) 45-47.

[11] Y. Jun Y, C. Qi. Antitumor Activities of Rauwolfia vomitoria Extract and Potentiation of Gemcitabine Effects Against Pancreatic Cancer. Integrative Cancer Therapies, 13(2014) 217225.

[12] J.I.A. Campbell, A. Mortensen, P. Molgaard, Tissue lipid lowering-effect of a traditional Nigeian antidiabetic infusion of Rauwolfia vomitoria foliage and Citrus aurantium fruit, Journal of Ethnopharmacology. 104 (2006) 379-386.

[13] M.A. Eluwa et al., Comparative study of teratogenic potentials of crude ethanolic root bark and leaf extract of Rauwolfia vomitoria (apocynaceae) on the fetal heart, North American Journal of Medical Science. 2 (2010) 592-595.

[14] E.M. Tekwu et al., In Vitro Assessment of Anthelmintic Activities of Rauwolfia vomitoria (Apocynaceae) Stem Bark and Roots against Parasitic Stages of Schistosoma mansoni and Cytotoxic Study, Hindawi Publishing Corporation Journal of Parasitology Research Volume 2017, Article ID 2583969, 11 pages http://dx.doi.org/10.1155/2017/2583969. 
[15] S.A. Attah et al., Extracts of Euphorbia hirta Linn. (Euphorbiaceae) and Rauwolfia vomitoria Afzel (Apocynaceae) demonstrate activities against Onchocerca volvulus Microfilariae in vitro, BMC Complementary and Alternative Medicine. 13 (2013) 2-10

[16] I.I. Ezeigbo et al., Antidiarrhoeal activity of leaf methanolic extract of Rauwolfia serpentine, Asian Pac J Trop Biomed, 2 (2012) 430-432.

[17] RNS Yadav, M. Agarwala. Phytochemical analysis of some medicinal plants, Journal of Phytology 3(2011): 10-14.

[18] H.O. Edoga, D.E. Okwu, B.O. Mbaebie. Phytochemicals constituents of some Nigerian medicinal plants, African Journal of Biotechnology 4(2005): 685-688

[19] E.O. Erhirhie, C.P. Ihekwereme, E.E Ilodigwe. Advances in Acute Toxicity Testing: Strengths, Weaknesses and Regulatory acceptance. Interdisciplinary Toxicology. 11 (2018) $5-12$.

[20] O.O. Adeyemi, A.J. Akindele E.A. Ogunleye Evaluation of the antidiarrhoeal effect of Sanseviera liberia Gerome and Labroy (Agavaceae) root extract, Journal of Ethnopharmacology. 123 (2009) 459-463.

[21] H. Sadraei, G. Asghari, H. Jamali. Antidiarrheal action of Zataria multiflora hydroalcoholic and hexane extracts in mice. J Herbmed Pharmacol 7(2018):22-8.

[22] J.O.T. Emudainohwo, G.E. Moke, D.E. Ejebe, E.O. Erhirhie. An investigation of the antidiarrhea effect of aqueous and ethanol stem bark extract of Alchornea cordifoliain Wistar rats. J Pharmacogn Phytochem 4(2015):183-187.

[23] C.O. Esimone, M.U. Adikwu, J.M. Okonta Preliminary antimicrobial screening of the ethanolic extract from the lichen Usnea subfloridans (L), J. Pharm. 3 (1998) 99-100.

[24] S.H. Taqvi, et at., Studies to determine anti-adiarrhoeal and spasmolytic activities of Extracts of Aegle marmelos. L. Fruit, Bangladesh journal of medicinal Science. 17 (2018) No. 2.

[25] L.C. Racusen, H.J. Binder. Ricinoleic acid stimulation of active anionsecretion in colonic mucosa of rat, J Clin Invest. 63 (1979): 743-749.

[26] S. Tunaru, T.F. et al, Castor oil induces laxation and uterus contraction via ricinoleic acid activating prostaglandin EP3 receptors. PNAS. 109 (2012) 9179-9184.

[27] M. Lakshminarayana, H. Shivkumar, P. Rimaben, V.K. Bhargava. Antidiarrhoeal activity of leaf extract of Moringa Oleifera in experimentally induced diarrhea in rats. International Journal of Phytomedicine; 3 (2011): 68-74.

[28] M. Peacock Calcium Metabolism in Health and Disease, Clin J Am Soc Nephrol. Supp 1 (2010) S23-S30.

[29] M.M. Islam et al Anti-diarrheal activities of Dilleniaindica bark extract IJPSR 4(2013) 682688.

[30] P.K. Ashok K. Upadhay Tannins are astringent. J Pharmacogn Phytochem. 1(2012) 45.

[31] A.B. Awad, J. Toczek C.S. Fink Phytosterols decrease prostaglandin release in cultured P388D1/MAB macrophages. PLEFA. 70 (2004) 511-520.

[32] M. Hamalanein et al., Effects of Flavonoids on prostaglandin E2 Production and on COX-2 and MPGES-1 Expressions in Activated Mcrophages, Planta Med., 77 (2011) 1504-1511.

[33] G.A. Pasewu, et al., Antibacterial activity of plants used in traditional medicines of Ghana with particular reference to MRSA Journal of Ethnopharmacology. 116 (2004): 102-111.

[34] M.A. Sonibare, T.O. Lawal, O.O. Ayodeji Antimicrobial Evaluation of Plants Commonly Used in the Management of Psychosis Opportunistic Infections International Journal of Pharmacology. 7 (2011) 492-497. 